\title{
Luxembourgish farmers' lack of information about grain legume cultivation
}

\author{
Stéphanie Zimmer ${ }^{1,4}$ - Ulf Liebe ${ }^{2}$ Jean-Paul Didier ${ }^{3}$. Jürgen Heß ${ }^{4}$
}

Accepted: 6 November 2015 /Published online: 15 December 2015

(C) INRA and Springer-Verlag France 2015

\begin{abstract}
Grain legume production in Europe has decreased in recent years, while legume demand has rapidly increased due to growth of meat production. Therefore, Europe imports grain legumes, principally soybeans, to meet feed protein requirements. Various investigations have identified problems and benefits of local grain legume cultivation. Nevertheless, grain legume cultivation has still not increased in the last years. Studies investigating why farmers do not cultivate grain legumes are missing. Here, we surveyed the knowledge of farmers about grain legume cultivation, problems and constraints of grain legume cultivation and the barriers faced by and incentives needed by farmers. We sent a questionnaire to 1373 farmers in Luxembourg, with a response rate of $29 \%$. Results show that only $17 \%$ of all the responding farmers cultivated grain legumes; $88 \%$ of the conventional farmers did not cultivate grain legumes, while $85 \%$ of the organic farmers did. We observed that Luxembourgish farmers feel badly informed about grain legume cultivation; organic farmers generally feel better informed than their conventional colleagues. The main barrier, named by Luxemburgish farmers to not cultivate grain legumes, is not economic issues
\end{abstract}

Stéphanie Zimmer

zimmer@ibla.lu

1 Institute for Organic Agriculture Luxembourg (IBLA), 13 rue Gabriel Lippmann (5365), Munsbach, Luxembourg

2 Institute of Sociology, Universität Bern, Fabrikstrasse 8 (3012), Bern, Switzerland

3 Ministère de l'Agriculture, de la Viticulture et de la Protection des consommateurs, Service d'Economie Rurale, 115, rue de Hollerich (1741), Luxembourg, Luxembourg

4 Universität Kassel, Organic Farming and Cropping Systems, Nordbahnhofstr. 1a (37213), Witzenhausen, Germany but a lack of knowledge and extension services for these crops. Main incentives needed to start grain legume cultivation in the future are economic issues. Even though grain legume producers mentioned several negative experiences with grain legume cultivation, they are not discouraged by the poor economic conditions and appreciate the benefits of grain legume cultivation. Overall, our findings show that research results on grain legume should be better disseminated to extension services and farmers.

Keywords Farmer survey · Grain legumes · Farmers' experiences $\cdot$ Protein deficit $\cdot$ Luxembourg

\section{Introduction}

Grain legumes are an important component of the global protein supply. However, protein crops are cultivated on only $3 \%$ of crop land in the European Union (Beste and Boeddinghaus 2011). The EU imports large quantities of soybean meal, mainly from South and North America, to cover its protein deficit: $80 \%$ of the protein consumption is presently imported every year (Beste and Boeddinghaus 2011). These imports have negative environmental and social impacts such as deforestation, loss of biodiversity, soil erosion, loss of soil quality, climate change, rural displacement, health problems and loss of food security, mainly occurring in the producer countries (Altieri and Pengue 2006; Leguizamón 2014). Imported soybeans pose a risk of contamination with genetically modified (GMO) soybeans (Nowack Heimgartner and Oehen 2003; Vindis et al. 2007). Increasing grain legume cultivation in Europe would solve these problems and would lead to a more sustainable global agriculture.

Due to their ability to fix nitrogen from the air symbiotically with rhizobia species, legumes are very important in 
agriculture, especially in organic production (Bedoussac et al. 2015). Legumes supply atmospheric $\mathrm{N}_{2}$ to subsequent crops when grown in rotation and incorporated into the soil. Grain legumes introduced into intensive crop rotations can reduce mineral $\mathrm{N}$ fertilizer need, energy use, global warming potential, ground level ozone formation, acidification, eco and human toxicity of conventional cropping systems and resource exhaustion (Nemecek et al. 2008; Köpke and Nemecek 2010; Jensen et al. 2012; Voisin et al. 2014). Legumes ameliorate soil structure; their deep and wide-spread root systems are able to mobilize mineral nutrients, mainly phosphorus, out of deeper soil layers (Nemecek et al. 2008; Peoples et al. 2009; Rühl et al. 2009; Köpke and Nemecek 2010; Jensen et al. 2012).

Grain legumes have low yield stability because of their high sensitivity to abiotic stresses (Freyer et al. 2005; LópezBellido et al. 2005; Voisin et al. 2014). Water deficiency combined with high temperatures at flowering can lead to leaf and flower abscission at ripening in various grain legume species (Stemann and Lütke Entrup 2001; López-Bellido et al. 2005). Weed infestation is often a problem due to grain legumes' slow juvenile development (Freyer et al. 2005). Selfincompatibility of most legume crops, mainly due to soilborne and residueborne disease and pests, such as crown and root rot complexes caused by Pythium, Aphanomyces, Fusarium, Verticillium, Phoma, Macrophomina and Rhizoctonia species, grey mould (Botrytis cinerea) and white mould (Sclerotinia sclerotiorum) and the migratory root lesion nematode Pratylenchus spp., is another problem that needs to be considered in the crop rotation (Davidson and Kimber 2007; Peoples et al. 2009; McDonald and Peck 2009; Stoddard et al. 2010; Finckh et al. 2015). These factors all limit grain legume cultivation.

Grain legumes are cultivated on $0.27 \%$ of Luxembourg's arable land (SER et al. 2013), which is low in absolute as well as relative terms compared to Germany (1\%), France (4\%), Switzerland (4 \%), Italy (5\%) and Spain (6.5\%) (Beste and Boeddinghaus 2011). The European Commission gives international trade agreements, namely the General Agreement on Tariffs and Trade (GATT) and the Blair-House agreement, as the reasons for low grain legume cultivation (Beste and Boeddinghaus 2011). The EU agreed to the unrestricted entry of oil and protein crops in exchange for more control over cereal production, especially from the USA. The specialization of agriculture during the 20th century also accounts for the progressive decrease of legumes in cropping systems (Voisin et al. 2014).

Various studies identify multiple problems and benefits of grain legume cultivation, but few investigate farmers' reasons for why they do not cultivate grain legumes (Fig. 1). In the GL-Pro study (Von Richthofen and Pfahl 2006; Charles et al. 2007), written questionnaires and interviews were conducted in Belgium $(N=66)$, Denmark $(N=5)$, France $(N=236)$,
Germany $(N=217)$, Spain $(N=96)$ and Switzerland $(N=111)$ to determine why more European farmers do not cultivate grain legumes. The main reasons given were low yields, low market prices and high seed costs. From this study, it was concluded that there exists a wide gap between the farmers' perceptions of the value of grain legumes and the economic facts of their relative competitiveness. In the GLPro study, grain legume producers were also asked, but their opinions were not thoroughly evaluated.

To understand why more grain legumes are not cultivated, it is important to know the challenges and opportunities all farmers face in order to develop successful agronomic strategies. Farmers' opinions on the cultivation of grain legumes were collected through a written survey to Luxembourgish farmers. The survey instrument sought to determine the potential for domestic production of protein crops for animal and human nutrition, increase the area of grain legume production and increase farmers' income. The following study aims (i) to determine the current level of information and knowledge of farmers about grain legumes; (ii) to identify the problems and constraints of grain legume cultivation (iii) and to identify the incentives needed for farmers to cultivate more grain legumes for various purposes.

\section{Materials and methods}

\subsection{Study area}

The study was conducted in Luxembourg, which has an area of $2586 \mathrm{~km}^{2}$. Luxembourg has two natural regions, the Oesling in the north, comprising $32 \%$ of the country's area and the Gutland in the south, which accounts for the remaining $68 \%$ of the land. The Oesling is part of the Rheinische Schiefergebirge (Rhenish slate mountain range) with its extended high plateau interrupted by deep river valleys. The Gutland has diverse soil types formed from lias and trias formations in the west.

Slightly over half of Luxembourg's land is in agricultural production (Table 1). The country has 2137 agricultural holdings and an average holding size of 61.5 ha. Most (72\%) of these farms are managed full time as the farmer's primary occupation; the rest are part-time enterprises (SER et al. 2013). Farmers have a mean age of 55 years. Contacted farms are 88.8 ha on average, and most (51\%) are dairy cattle or suckler cow operations. Organic production methods were used by $3.1 \%$ of the farms contacted accounting for $2.7 \%$ of the area included in the survey.

\subsection{Farmers' survey}

In August 2012, a questionnaire written in German was sent by post to every agricultural farm manager in Luxembourg of 
Fig. 1 Farmers' interest in grain legumes is high, but there is a huge gap of knowledge about these crops
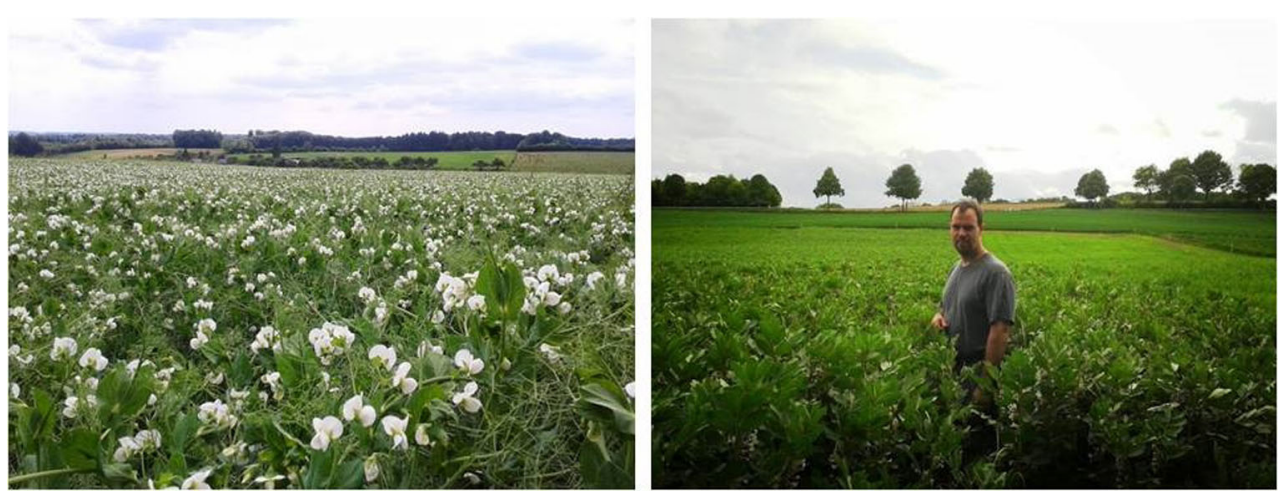

farms with over 5 ha arable land; a total of 1373 farmers were contacted. The criterion to send the survey only to farmers who manage more than 5 ha guaranteed that part-time farmers are not overrepresented. To protect anonymity, the questionnaire was mailed by the "Service d'Economie Rural (SER)" of the Ministry of Agriculture, Viticulture and Consumer Protection (MA). A reminder was sent to the farmers in November 2012. The questionnaire was sent again 6 months after first distribution, in February 2013 (Dillman 1991).

The questionnaire consisted of 17 pages and was divided into three parts:

1. Description of the farm including utilised agricultural land, full or part-time, age of the farm manager (open question), economic specialisation (closed-ended question), conventional or organic management, crop rotation (open question), technical facilities of the farm (closed-ended question) and information about the origin of protein fodder (closed-ended question).

2. Level of information and knowledge about grain legumes of the respondent, consisting of questions about information degree (five-point response scale), preferred information source (closed-ended question where multiple answers were allowed combined with open question part) and need for research and information (open-ended question).

3. The third part included a filter so that farmers received different questions depending on whether they had or had not cultivated grain legumes at the time of the survey, including whether they had in the past and no longer did so.

Farmers who did not cultivate grain legumes were asked why not, with multiple choices combined with an open question. These farmers were also asked what incentives would

Table 1 Characteristics of the three farmers groups (total, contacted, responding) in Luxembourg in 2012

\begin{tabular}{|c|c|c|c|c|c|c|}
\hline \multirow{2}{*}{$\begin{array}{l}\text { Farm description } \\
\text { Number of farms }\end{array}$} & \multicolumn{2}{|c|}{ All farmers in Luxembourg (total) } & \multicolumn{2}{|c|}{ Contacted farmers } & \multicolumn{2}{|c|}{ Responding farmers } \\
\hline & 2137 & $(100 \%)$ & 1373 & $(100 \%)$ & 400 & $(100 \%)$ \\
\hline Combined utilised agricultural area (ha) & 131,492 & $(100 \%)$ & 122,527 & $(100 \%)$ & 35,666 & $(100 \%)$ \\
\hline Arable land (ha) & 62,563 & $(47.6 \%)$ & 61,334 & $(50.1 \%)$ & 17,156 & $(48.1 \%)$ \\
\hline Grassland (ha) & 67,292 & $(51.2 \%)$ & 61,069 & $(49.8 \%)$ & 18,348 & $(51.4 \%)$ \\
\hline Grain legumes (ha) & - & & 276 & $(0.2 \%)$ & 230 & $(0.7 \%)$ \\
\hline Organically managed combined utilised agricultural area (ha) & 3580 & $(2.7 \%)$ & 3366 & $(2.7 \%)$ & 1848 & $(5.2 \%)$ \\
\hline Organically managed farms & 66 & $(3.1 \%)$ & 43 & $(3.1 \%)$ & 27 & $(6.8 \%)$ \\
\hline full-time farms & 1544 & $(72.3 \%)$ & 1259 & $(91.7 \%)$ & 364 & $(91.0 \%)$ \\
\hline Mean age of farmers & - & & 53 & & 49 & \\
\hline Average combined utilised area per farm (ha) & 62 & & 89 & & 89 & \\
\hline \multicolumn{7}{|l|}{ Economic orientation } \\
\hline Dairy cattle (farms) & 575 & $(26.9 \%)$ & 489 & $(35.6 \%)$ & 161 & $(40.3 \%)$ \\
\hline Suckler cows (farms) & 375 & $(17.6 \%)$ & 157 & $(11.4 \%)$ & 50 & $(12.5 \%)$ \\
\hline Dairy cattle and suckler cows (farms) & 146 & $(6.8 \%)$ & 63 & $(4.6 \%)$ & 76 & $(19.0 \%)$ \\
\hline Arable farming (farms) & 170 & $(8.0 \%)$ & 96 & $(7.0 \%)$ & 28 & $(7.0 \%)$ \\
\hline Pig fattening (farms) & 29 & $(1.4 \%)$ & 29 & $(2.1 \%)$ & 6 & $(1.5 \%)$ \\
\hline Different economic orientation (farms) & 842 & $(39.4 \%)$ & 539 & $(39.3 \%)$ & 79 & $(19.8 \%)$ \\
\hline
\end{tabular}

Absolute numbers and relative numbers for the respective category in brackets 
encourage them to cultivate these crops in the future (open question).

Farmers who cultivated grain legumes were asked when they started cultivating grain legumes and which species they cultivate in pure stands (closed-ended question) or in mixtures (open question). They were asked from where they got their knowledge about grain legume cultivation (closed-ended question where multiple answers were allowed) and about their positive and negative experiences with the cultivation of grain legumes (closed-ended question where multiple answers were allowed combined with an open question part). They were questioned about their use of grains they produced (closed-ended question where multiple answers were allowed) and their incentives for further grain legume cultivation on their farm (open question).

\subsection{Data analysis}

In a first step, answers were digitalised, and the data was checked for errors and missing values. In a second step, a descriptive and bivariate analysis (Pearson's chi-squared $\left(\chi^{2}\right)$ test) was carried out using SPSS (Wittenberg and Cramer 2003) " $N$ " is the total of the responding farms, and " $n$ " is the number of farmers who answered a specific question.

\section{Results and discussion}

Exactly 400 of the 1373 contacted farms responded to the survey for a response rate of $29 \%$, which is a good value for mail surveys (The American association for public opinion research 2011). Unless otherwise mentioned, all results reported for farms refer to those that responded to the survey.

\subsection{Description of the farms}

Table 1 compares the results with summary statistics of all Luxemburgish farm managers. The population is well represented in the sample.

Responding farm managers used $48 \%$ of their agricultural area as arable land, which is close to the $50 \%$ average for contacted farm managers and the $48 \%$ average for Luxemburgish farm managers in general. Average combined utilised agricultural area of the responding farms was close to the area of the contacted farms but was higher than the average combined utilised area of all Luxemburgish farms. The selection criteria that only farms with more than 5 ha arable land were contacted can explain the discrepancy.

In contrast to Luxemburgish agriculture, full time farms are overrepresented with $91 \%(n=399)$, which again can be explained by the criterion to survey farms over 5 ha. Slightly more than half $(51.3 \%)$ of all farms in Luxembourg and the farms contacted $(51.6 \%)$ were dairy or cattle farms. Cattle and cow farms were overrepresented in the responses $(71.8 \%)$, which might indicate a higher interest of these farmers in the grain legume subject.

The percentage of organically managed farms contacted was identical to the percentage in Luxembourg agricultural overall (Table 1), and the percentage of the responding farms that are organically managed was substantially higher $(6.8 \%)$ than for the contacted farms (3.1\%). Of the contacted organic farmers, $62.8 \%$ participated in the survey, whereas only $28 \%$ of the conventional farmers did so. The higher interest from the organic sector might be due to a better knowledge about the positive effects of legumes in crop rotation. Furthermore, organic farmers have more experience with the cultivation of grain legumes. Responding organic farmers $(6.8 \%$ of the responding farmers) cultivate $33 \%$ of the total grain legume cropping area of all the responding farmers. Of the organic arable land, $7.9 \%$ is used for grain legume cultivation, whereas grain legumes are cultivated on only $1 \%$ of conventional arable land. A further reason for the overrepresentation of organic farmers could be that the Institute for Organic Agriculture Luxembourg is responsible for the survey. Since Luxembourg is very small and has only very few stakeholders in organic agriculture, people and farmers involved know each other and also know the author of the survey and therefore might feel more obliged to participate in the survey than their conventional colleagues.

The crop rotation practiced on the farms ranges from one to ten crops: almost a third of farms (32\%) had three crops in rotation, followed by over a quarter $(26 \%)$ with four crops in rotation. Only $6 \%$ of the farms had more than six crops in rotation and eight farms had monoculture on their fields $(n=346)$. Between a quarter and a third of the farms worked with catch crops $(n=346)$. In $96 \%$ of the rotations, cereals were cultivated, followed by root crops (62\%) (primarily corn, followed by potato and carrot), field forage (43\%) and rapeseed $(28 \%)$. Grain legumes were only cultivated in $7 \%$ of the rotations $(n=346)$. Farms that cultivate grain legumes had on average 4.7 crops in rotation, whereas farms that did not cultivate grain legumes only had 3.8 crops in rotation. When cultivating grain legumes, this crop is integrated as an extra crop in rotation and does not simply replace another crop. Grain legumes were integrated in $44.4 \%$ of the organic crop rotations and only in $3.5 \%$ of the conventional crop rotations.

Technical equipment of the farms varied. A corn mill was present on $32 \%$ of the farms $(n=390)$, Almost $14 \%$ of the farms had capacity to dry grains $(n=392)$, about $10 \%$ owned a grain cleaner $(n=384)$ and $8.6 \%$ a cereal crusher $(n=383)$. Only three farms possessed a rapeseed oil press $(n=378)$.

The majority of the farms purchased protein fodder (63\%), and only $37 \%$ used the protein feed out of their own production as main protein source $(n=328)$. For organic farmers, a much higher proportion $(80 \%)$ produce their own protein 
fodder, compared with only about a third (34\%) of the conventional farmers. Schader et al. (2011) determined a much higher self-sufficiency in protein fodder for organic farms than for conventional farms in Luxembourg. Self-sufficiency in protein fodder was $95 \%$ for organic and $52 \%$ for conventional dairy cattle farms. For cow suckler farms, it was $89 \%$ for the organic and $79 \%$ for the conventionally managed farms. The higher self-sufficiency of organic farms can be explained by a longer experience of organic farmers with grain legumes and the fact that they are dependent on the beneficial effects of the legumes in their rotation: they not only learned how to use grain legumes for their beneficial effects on soil fertility but subsequently also learned how to integrate the harvested grains in their fodder ration with respect to the different dietary requirements of the different animals (monogastric, ruminants).

\subsection{Farmers' knowledge about grain legumes}

Farmers were asked how well-informed they felt about grain legume cultivation (Fig. 2). Most of the farmers (40.8\%) felt badly informed, $22.3 \%$ felt well-informed and $36.9 \%$ felt partly badly and partly well-informed $(n=382)$. Organic farmers felt better informed about grain legume cultivation (52\% well-informed, $n=27$ ) than conventional farmers (20\% well-informed, $n=354$ ). This can be explained by the fact that organic farmers have more experience with grain legume cultivation.

Many farmers would prefer to receive more information on grain legume cultivation from an extension service, brochures and technical magazines (44, 44 and $42 \%$ respectively, $n=380$ ). In an open question concentrating on grain legumes, farmers were asked to name the field where they felt that further research was needed to be done and more information had to be made available (Table 2).

The top research topics identified by non-grain legume producers were varieties, yield and cultivation and technique. Most farmers feel poorly informed about grain legume cultivation, and they especially would like to be informed about the technical aspects of grain legume cultivation and the possibility of using grain legumes in animal nutrition; economic issues are only in third place. Farmers clearly prefer information from a specialised agricultural extension service. This service is not available to all farmers in Luxembourg, where only the organic farming extension service has sufficient experience with grain legume cultivation, but at present, this service is only available for organic farmers.

Farmers who did not produce grain legumes differed in their responses from the farmers who cultivated grain legumes (Table 2). Grain legume producers prioritised information and further research in the areas of varieties, weed management and yield $(15 \%)(n=48)$. Grain legume producers also ranked fodder use as a priority, which may indicate that they cultivate grain legumes but do not know how best to use these crops as fodder. Their answers also show that grain legume producers are well-informed about the problems in cultivation. Varieties, weed management, resistance to lodging and yield stability are problems which are well known in research. Many farmers are interested in soybeans, which might be explained by the promotion of their cultivation in Europe in recent years. Current non-producers seem to be keenly interested in this "new" crop.

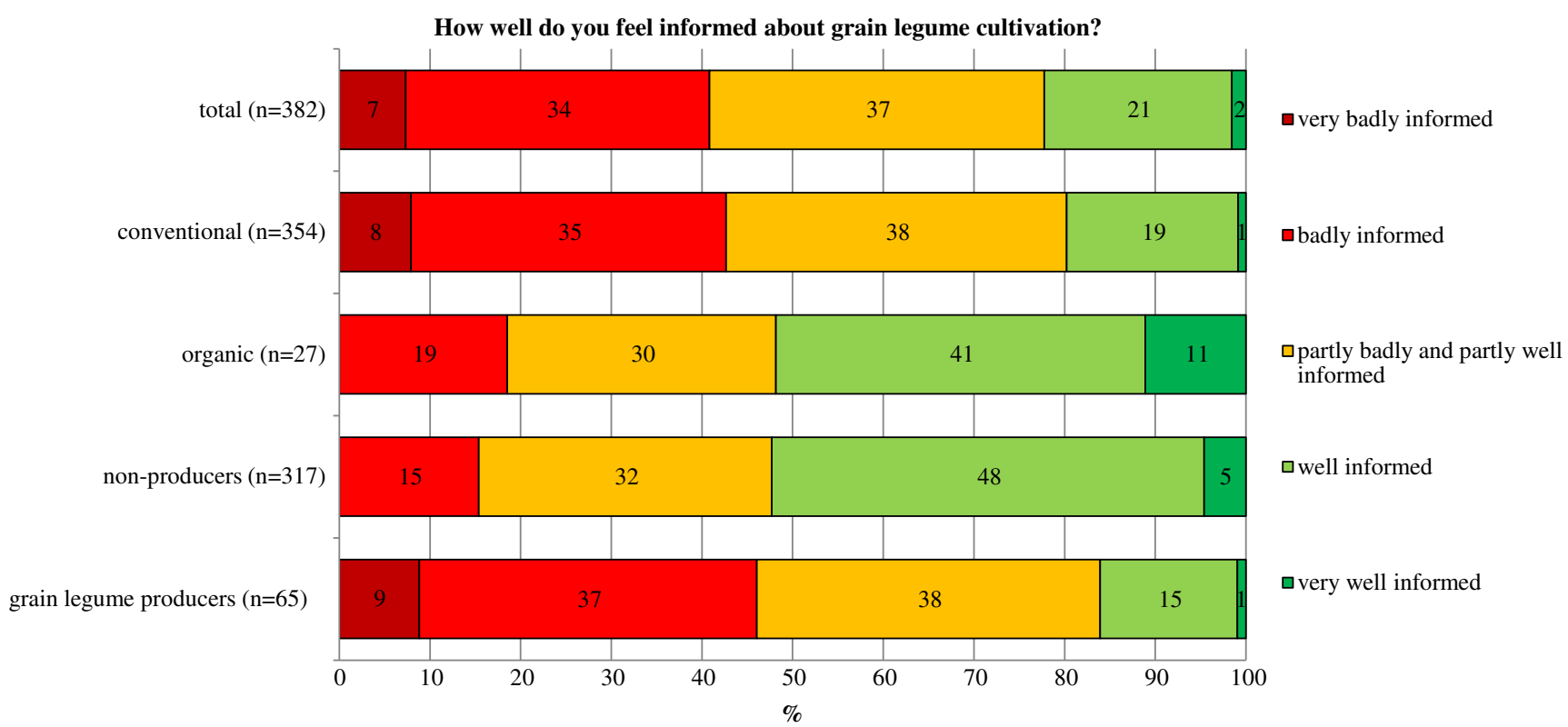

Fig. 2 Percentage of information degree about grain legume cultivation of the farmers (total: $n=382$; conventional $n=354$; organic $n=27$; grain legume producers $n=317$; non-producers $n=65$ ). Answers were given on a five-point response scale: very badly informed, badly informed, partly badly and partly well informed, well informed and very well informed. Most of the farmers felt badly informed. Organic farmers felt better informed about grain legumes cultivation than conventional farmers 
Table 2 Need of information and research concerning grain legumes according to the responding farmers (total: $n=174$, non-grain legumes producer: $n=127$, grain legume producer: $n=48$ )

\begin{tabular}{|c|c|c|c|c|c|c|}
\hline \multirow[b]{2}{*}{ Subject } & \multicolumn{2}{|c|}{ Total $(n=174)$} & \multicolumn{2}{|c|}{ Non-grain legume producer $(n=127)$} & \multicolumn{2}{|c|}{ Grain legume producer $(n=48)$} \\
\hline & Absolute & Percentage & Absolute & Percentage & Absolute & Percentage \\
\hline Varieties & 38 & 21.8 & 25 & 19.7 & 13 & 27.1 \\
\hline Yield & 35 & 20.1 & 28 & 22.0 & 7 & 14.6 \\
\hline Cultivation and technique & 31 & 17.8 & 26 & 20.5 & 5 & 10.4 \\
\hline Soybean cultivation & 25 & 14.4 & 20 & 15.7 & 5 & 10.4 \\
\hline Use as fodder & 24 & 13.8 & 17 & 13.4 & 7 & 14.6 \\
\hline Breeding & 18 & 10.3 & 14 & 11.0 & 4 & 8.3 \\
\hline Plant protection & 17 & 9.8 & 12 & 9.4 & 5 & 10.4 \\
\hline Weed management & 16 & 9.2 & 6 & 4.7 & 10 & 20.8 \\
\hline Proceeding facilities & 15 & 8.6 & 13 & 10.2 & 2 & 4.2 \\
\hline Economic profitability & 15 & 8.6 & 12 & 9.4 & 3 & 6.3 \\
\hline Soil requirements of the different grain legumes & 15 & 8.6 & 13 & 10.2 & 2 & 4.2 \\
\hline Climate requirements & 12 & 6.9 & 10 & 7.9 & 2 & 4.2 \\
\hline Resistance to lodging & 8 & 4.6 & 2 & 1.6 & 6 & 12.5 \\
\hline Crop rotation, self-compatibility & 8 & 4.6 & 4 & 3.1 & 4 & 8.3 \\
\hline Site requirement in general & 8 & 4.6 & 6 & 4.7 & 2 & 4.2 \\
\hline
\end{tabular}

"Where do you see, in your opinion, a need for more information and further research concerning grain legumes?" Open ended question, where answers were categorised and multiple answers were allowed. Top research topics given by all the responding farmers (total) were similar to those given by the non-grain legume producers, namely varieties, yield and cultivation and technique, and differed in part from those given by the grain legume producers (weed management, use as fodder, resistance to lodging). Only subjects with more than $4 \%$ responses are reported.

\subsection{Experience of farmers who do not cultivate grain legumes}

Grain legumes were not yet cultivated by 229 farmers and 104 had already cultivated grain legumes in the past but did not do so anymore $(n=400)$ (Fig. 3$)$.

The farming system of the farm (conventional or organic) had a significant influence on grain legume cultivation. A majority of conventional farmers $(88 \%)$ did not cultivate grain legumes, while $85 \%$ of the organic farmers cultivated grain legumes. Farmers who did not cultivate grain legumes $(83 \%)$ were asked to explain why not; multiple answers were possible. The following reasons were named by more than $10 \%$ $(n=315)$ : missing information and knowledge (44\%), problems at harvest (36\%), yield fluctuations (31\%), low yields (30\%), low profitability compared to cereals (25\%), personal preference for other crops $(24 \%)$, low competiveness with oilseeds (19\%), lower cost to buy protein fodder than to produce it (18\%), low profitability compared to corn, potato and other root crops $(17 \%)$, missing processing industry for fodder production (17\%), problems with weed regulation $(16 \%)$, land is used differently/not enough arable land (14\%), no public support (14\%), grain legumes do not fit the present soil (13\%) and grain legumes are not viable as fodder crop (11\%). It is worth noting that missing information and knowledge is the main reason that explains why farmers do not cultivate grain legumes. Half of the farmers felt badly informed about grain legume cultivation and had not yet cultivated grain legumes, whereas a quarter of the farmers felt well-informed and had already cultivated grain legumes. There is a statistically significant association between the information degree and the cultivation of grain legumes $\left(\chi^{2}=54.233, p<0.0001\right)$.

Problems with harvest and yield are a major issue with economic issues in third place. Farmers think that it is cheaper to buy protein fodder than to produce it themselves. When protein imports are cheap, it may be less expensive and easier for the farmer to cultivate and sell cereals and to buy protein fodder than to produce protein on his farm. In particular, this can be expected when farmers have greater experience and knowledge of producing cereals rather than protein crops.

Reasons why Luxemburgish farmers do not cultivate grain legumes are similar to the reasons found in the GL-Pro study (Von Richthofen and Pfahl 2006; Charles et al. 2007) in Belgium, Germany, Spain, France and Switzerland. In the GL-Pro study, low grain yield, low marked prices and high seed costs were the main reasons. Missing information and knowledge were not named in the GL-Pro study; however, a reason therefore could be the way the questions were set up. The GL-Pro asked a closed-ended question combined with an open question part but did not include an option to answer "missing information and knowledge" in the closed-ended question, as was done in the Luxemburgish study.

Economic issues were named as a top reason in the open question about the incentives for farmers to cultivate grain 


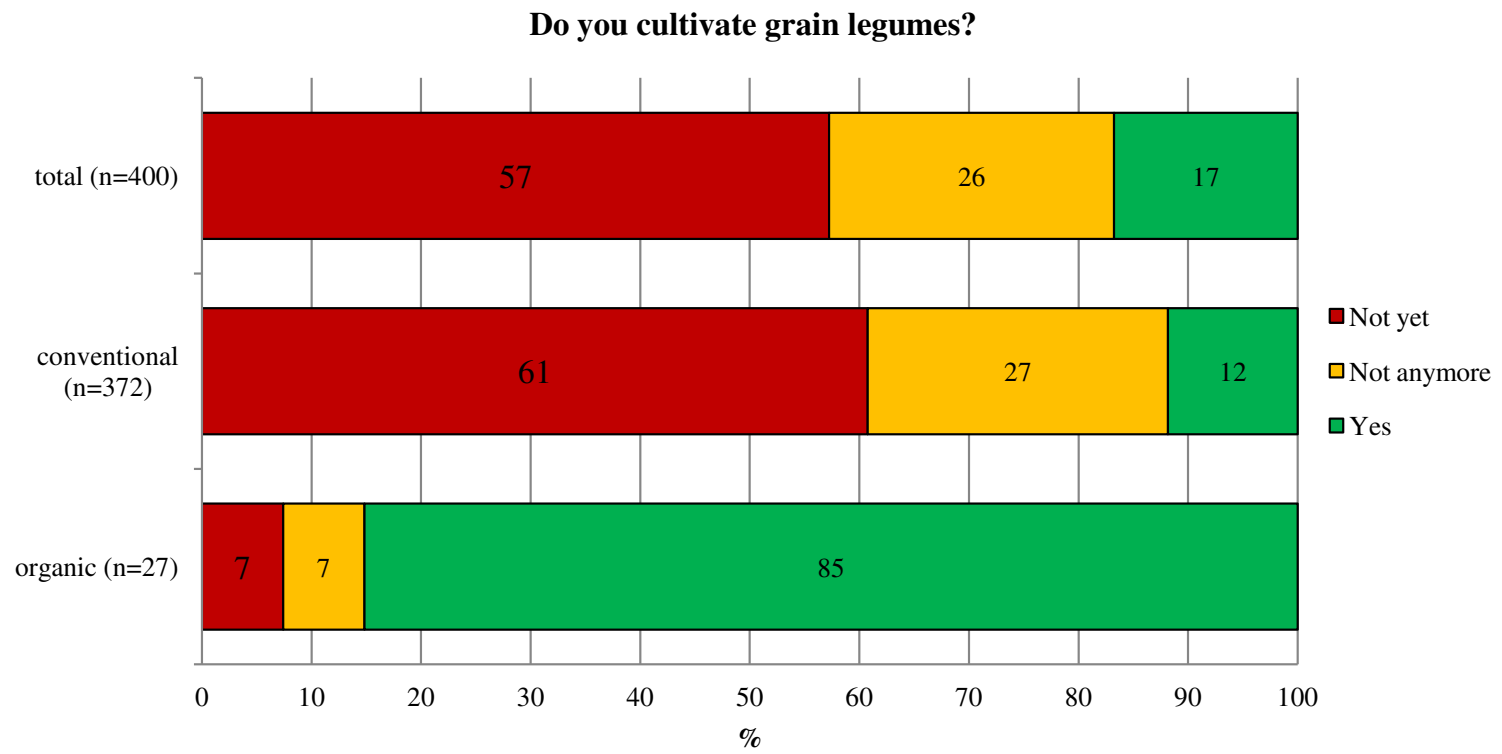

Fig. 3 Percentage of farmers cultivating, not anymore and not yet cultivating grain legumes, shown for all the responding farmers (total) $(n=400)$, the responding conventional farmers $(n=372)$ and the responding organic farmers $(n=27)$. Only $17 \%$ of all the responding

legumes in the future. Higher profit margin and marketing were named by $26 \%$ of the responses, the increasing protein fodder prices/cheaper alternatives to imported protein fodder by $18 \%$, extension and information by $17 \%$, public support by $15 \%$, higher and constant yields by $14 \%$, adapted varieties by $11 \%$ and more and adequate arable land available by $10 \%$. The reason that economic issues were top ranked could be the difficulty for Luxemburgish farmers to use or sell grain legumes after harvest. Only $14 \%(n=392)$ of the farmers have the capacity to dry grains on their farm, which is necessary for storage. Cleaning the grains after harvesting is often necessary, particularly because $16 \%$ of the farmers $(n=315)$ reported problems with weeds, but only $10 \%(n=384)$ of the farms have the possibility to clean grains. Luxembourg lacks a grain legume processing industry. There are no soybean toasting systems in Luxembourg and border regions. Without the capacity or infrastructure needed to process grain legumes for human or animal consumption, market opportunities are limited.

After the economic issues, extension and information were named as important incentives for non-grain-legume-producers to cultivate grain legumes. In the comments section of the survey, many farmers also underlined once more that they first need information about grain legumes before they could or would decide to cultivate these crops. They would appreciate ongoing assistance by a specialised extension service while trying out grain legume cultivation for the first time. One possible way to help farmers gain access to information and experience about grain legume cultivation would be by organising a network of farmers, including those that already cultivate grain legumes and those interested in doing so, supported by a specialised extensionist. This group could visit each other's fields and farmers cultivated grain legumes. A majority of conventional farmers $(88 \%)$ did not cultivate grain legumes, while $85 \%$ of the organic farmers cultivated grain legumes

exchange experiences about problems with grain legume cultivation. Organic farmers in particular could lead such a group.

The farm size played an important role in the decision-making. Many farmers felt that they did not have enough arable land for grain legume cultivation $(14 \%, n=318)$. This statement was also mirrored in the agricultural utilised area of the two groups: farms which cultivated grain legumes had on average more agricultural utilised area (93.1 ha) and more farmland (48.9 ha) than those which did not cultivate grain legumes (88.6 ha utilised agricultural area, 41.8 ha farmland). However, grain legumes can be successfully used in rotation and intercropping systems (Bedoussac et al. 2015) and can therefore also be incorporated in crop rotations on farms with less arable land. Here, the lack of knowledge on grain legume cultivation affects again the decision-making process. Therefore, good agricultural extension services are needed to show not only the benefits of grain legumes and how they can be used as animal fodder but also how grain legume cultivation is possible and profitable even with less arable land.

\subsection{Experiences of farmers who cultivate grain legumes}

Of the 400 responding farmers, 171 farmers had already cultivated grain legumes and 67 of them (16.8\%) still did so (Fig. 3). Half of the farmers who cultivated grain legumes had between 11 and 30 years of experience in grain legume cultivation $(n=54)$. The farmers that cultivate grain legumes had an average age of 49 years, which is the same as the average of all the responding farmers. Farmers who cultivate grain legumes were likely to be in their 50s (46\%). Farmers who did not cultivate grain legumes were generally between 35 and 49 years 
old (39\%). One reason why younger farmers do not cultivate grain legumes might be that in the last 20-30 years, grain legumes had no priority in education and extension services.

Farmers' knowledge about grain legume cultivation originated mainly from trying out grain legume cultivation by themselves (81\%), extension (43\%), technical magazines (39\%), transmission from generation to generation (31\%), technical literature $(27 \%)$ and internet $(19 \%)(n=67)$. As confirmed in the comments section of the survey, farmers who tried to cultivate grain legumes and had poor results might abandon these crops. Spring pea (92\%), spring faba bean (49\%) and blue lupin $(23 \%)$ were the main grain legume species cultivated, primarily in pure stand $(n=61)$. Preferred cultivated mixtures were pea-oat (47\%) and pea-barley $(29 \%)(n=34)$. Farmers named in total 24 different mixtures that included grain legumes; this shows that farmers are experimenting, but only pea-oat and pea-barley were widely adopted. As mentioned earlier, farmers who cultivated grain legumes had on average 4.7 crops in rotations and most farmers had 5 or 6 crops in rotations. For faba bean and lupin, a cultivation break of at least 4 years is recommended (Stoddard et al. 2010; Böhm et al. 2014; Finckh et al. 2015), and for pea, the recommendation is for an even longer 6-10 years interval (McDonald and Peck 2009; Jensen et al. 2012; Böhm et al. 2014; Finckh et al. 2015), mainly because of soilborne and residueborne diseases and pests. Knowing that $28 \%$ of the farmers who cultivate grain legumes have 3 or 4 crops in rotation and that spring pea is the major crop cultivated, upcoming negative effects, such as diseases and following decreases in yield, due to a too short cultivation break (Davidson and Kimber 2007; Böhm et al. 2014) can be expected. This could partly explain the negative experiences concerning grain legume cultivation farmers named in a closed-ended question, where multiple answers were possible $(n=61)$. As negative experiences, most of the farmers thought of unstable yields $(71 \%)$, followed by problems at harvest (57\%) and with weed management (54\%). Many farmers were unsatisfied because of low yields (38\%), and $33 \%$ assessed that profit margins compared with cereals were too low. High seed cost $(28 \%)$ and missing public support $(16 \%)$ were named as problems. While organic farmers are perceived to have more difficulties with weed management, this was not the case for grain legumes. There exists no relation between management (conventional or organic) and the problems with weed regulation $\left(\chi^{2}=0.119, p=0.73\right)$. Negative experiences are ranked the same for organic and conventional managed farms and include cultivation problems, unstable und low yields. It is interesting to note here that farmers who did not produce grain legumes did not name weed management as one of the main reasons for not cultivating grain legumes, whereas weed management is listed by the grain legume producers as one of the main problems encountered in grain legume cultivation. Those who do not produce grain legumes (57\%, Fig. 3) may not know that weed control is a major cultivation problem, and this illustrates again the lack of knowledge about grain legume cultivation among non-grain legume producers.

Farmers were also asked about their positive experiences with grain legume cultivation. Positive experiences identified by more than $25 \%$ of the responses are reported. Top ranked was the positive effect on soil fertility ( $81 \%)$, followed by fertilizer cost savings (78 \%), high previous crop value (69\%), extension of crop rotation (64\%), cover of the demand of protein fodder of the farm by own production (54\%), grain legumes match to own soil conditions (39\%), and it is cheaper to produce protein fodder at own farm than to buy it $(27 \%)$ $(n=67)$. Main positive experiences with grain legumes are in context with the soil type and fertility, and only in the second place were the economic issues relevant. This shows that farmers who cultivate grain legumes are aware of the beneficial effects of grain legumes to soil fertility and biodiversity. Furthermore, they also see economic benefits while cultivating grain legumes.

A majority of the farms (56\%) used the grain legumes from their fields as farmhouse feeding stuff for dairy cattle, $54 \%$ for farmhouse beef fodder, $23 \%$ as green manure and $21 \%$ sold it to feed production industry $(n=57)$. This shows that grain legumes are mainly produced for animal fodder especially for ruminants. Cleaning and drying are necessary to store grain legumes. Farmers who cultivate grain legumes also have more often the possibility to dry grains $(28.4 \%, n=67)$ compared to farms that do not cultivate these crops $(10.5 \%$, $n=325)$. The capacity to clean grains was reported by $38 \%$ ( $n=66)$ of the grain legume-cultivating farms and was on only $4 \%(n=318)$ of the non-cultivating farms. The results confirm that processing facilities are important for an increase of grain legume cultivation.

Farmers who used grain legumes as farmhouse feeding stuff, fed them mostly as milled grains (61\%), crushed grains $(57 \%)$ or as total plant silage $(43 \%)(n=46)$. Furthermore, farmers who cultivated grain legumes were asked in an open question about their incentive to continue cultivating grain legumes. Many of the farmers would continue cultivating grain legumes without condition ( $21 \%$ ), $18 \%$ would cultivate these crops in the future if yields were to become higher and more stable and $15 \%$ would do so if marketing and economics were guaranteed $(n=39)$. There was no correlation between farmers who continue cultivating grain legumes without condition and whether the management of the farm was conventional or organic $\left(\chi^{2}=0.041, p=0.84\right)$. The relatively large number of farmers that continue to cultivate grain legumes shows the farmers' commitment to these crops. Low and unstable yields pose difficulties for farmers that cultivate grain legumes, as well as pose a barrier in terms of introducing grain legume cultivation in their crop rotation for those who do not. Farmers pointed out a need for information and research on many issues such as varieties, yield, cultivation and technique, 
breeding, plant protection and weed management. Farmers and researchers share the same priorities (Böhm 2009).

\section{Conclusion}

The response rate of $29 \%$ verifies that there is a substantial interest in grain legume cultivation among Luxembourgish farmers. Only $17 \%$ of all the responding farmers cultivated grain legumes; $88 \%$ of the conventional farmers did not cultivate grain legumes, while $85 \%$ of the organic farmers did. It has been shown that Luxembourgish farmers feel badly informed about grain legume cultivation and that organic farmers generally feel better informed than their conventional colleagues. The main reasons named by Luxemburgish farmers to not cultivate grain legumes are a lack of information and extension services for these crops, followed by cultivation problems and poor economic conditions. As main incentive to cultivate grain legumes in the future, economic issues were named. Even though grain legume producers mentioned several negative experiences with grain legume cultivation, they are not discouraged by the poor economic conditions, and they appreciate the benefits of grain legume cultivation, e.g. soil fertility, fertilizer cost savings, high previous crop value, extension of crop rotation and increased fodder self-sufficiency. Even grain legume producers, who generally feel better informed about grain legume cultivation, say that their main source of knowledge about grain legumes is from trying it out themselves, and many of the issues mentioned by them have already been treated in literature, e.g. unstable yield, problems at harvest and weed management.

It is clear from the study at hand that the lack of information and knowledge about grain legume cultivation are the main barriers in grain legume production. The existing knowledge and research results need to be made available to farmers. Establishment of good extension services and demonstration projects as well as dissemination of research results from research through these extension services into practice, mainly about cultivation techniques and the use of grain legumes as animal fodder, are key to increase grain legume production in Luxembourg and Europe. This would lead to a reduction in soybean imports and would contribute to a more sustainable global agriculture.

However, it is important not only to close the gap of knowledge but also to build incentives for grain legume cultivation, mainly by establishing regional processing facilities and by supporting grain legume production by public aids, e.g. Greening.

To decrease soybean imports, Luxembourg must also improve its use of fodder legumes and grass as protein sources for ruminants. Farmers who want to increase milk production per cow or fatten cattle can replace imported soybean meal with regionally produced grain legumes. Finally, locally cultivated and properly handled grain legumes can help Europe achieve a higher level of self-sufficiency in the monogastric animal stock sector.

Acknowledgements The present project is supported by National Research Fund, Luxembourg. Thanks to all the sponsors who supported the project "LegoLux". Thanks to Dr. Thorsten Haase for the support while editing the questionnaire. Thanks to Jacques Miltgen and Joshi Zimmer for digitalising the answers. Thanks also to Charles Margue, Tommy Klein and Thomas Krikser for the support in statistics. Thanks to Evelyne Stoll and Gerber van Vliet for spell checking. Many thanks for all the farmers participating in the survey.

\section{References}

Altieri M, Pengue W (2006) GM soybean: Latin America's new coloniser. Seedling 1:13-17

Bedoussac L, Journet E-P, Hauggaard-Nielsen H et al (2015) Ecological principles underlying the increase of productivity achieved by cereal-grain legume intercrops in organic farming. A review. Agron Sustain Dev 35:911-935. doi:10.1007/s13593-014-0277-7

Beste A, Boeddinghaus R (2011) Artenvielfalt statt Sojawahn. Martin Häusling MDEP 33

Böhm H (2009) Körnerleguminosen-Stand des Wissens sowie zukünftiger Forschungsbedarf aus sich des Okologischen Landbaus. J Für Kult 61:324-331

Böhm H, Bohne B, Brandhuber R et al (2014) Körnerleguminosen und Bodenfruchtbarkeit: Strategien für einen erfolgreichen Anbau. Bundesanst Für Landwirtsch Ernähr 60

Charles R, Gaume A, Von Richthofen J-S (2007) Auswertung des Körnerleguminosenanbaus durch die Produzenten. AGRARForschung 14:300-305

Davidson JA, Kimber RBE (2007) Integrated disease management of ascochyta blight in pulse crops. Eur J Plant Pathol 119:99-110. doi:10.1007/s10658-007-9132-x

Dillman DA (1991) The design and administration of mail surveys. Annu Rev Sociol; 17:225-249

Finckh MR, van Bruggen AHC, Tamm L (eds) (2015) Plant diseases and their management in organic agriculture. The American Phytopathological Society, St. Paul, Minnesota

Freyer B, Pietsch G, Hrbek R, Winter S (2005) Futter- und Körnerleguminosen im biologischen Landbau. AvBuch, Leopoldsdorf

Jensen ES, Peoples MB, Boddey RM et al (2012) Legumes for mitigation of climate change and the provision of feedstock for biofuels and biorefineries. A review. Agron Sustain Dev 32:329-364. doi:10. 1007/s13593-011-0056-7

Köpke U, Nemecek T (2010) Ecological services of faba bean. Field Crops Res 115:217-233. doi:10.1016/j.fcr.2009.10.012

Leguizamón A (2014) Modifying Argentina: GM soy and socioenvironmental change. Geoforum 53:149-160. doi:10.1016/j. geoforum.2013.04.001

López-Bellido FJ, López-Bellido L, López-Bellido RJ (2005) Competition, growth and yield of faba bean (Vicia faba L.). Eur J Agron 23:359-378. doi:10.1016/j.eja.2005.02.002

McDonald GK, Peck D (2009) Effects of crop rotation, residue retention and sowing time on the incidence and survival of ascochyta blight and its effect on grain yield of field peas (Pisum sativum L.). Field Crops Res 111:11-21. doi:10.1016/j.fcr.2008.10.001

Nemecek T, von Richthofen J-S, Dubois G et al (2008) Environmental impacts of introducing grain legumes into European crop rotations. Eur J Agron 28:380-393. doi:10.1016/j.eja.2007.11.004 
Nowack Heimgartner K, Oehen B (2003) Analyse von GVOVerunreinigungen in Bioprodukten Belastungsgrade und Vermeidungsmöglichkeiten in Saatgut, Lebensmitteln und Futtermitteln. Bundesamt Für Umw Wald Landsch 50.

Peoples MB, Brockwell J, Herridge DF, et al (2009) The contribution of nitrogen-fixing crop legums to the productivity of agricultural systems. Symbiosis 48:1-17.

Rühl G, Bramm A, Greef J (2009) Aspekte des Anbaus von Körnerleguminosen. J Für Kult 61:312-317

Schader C, Müller A, Zimmer S, et al (2011) Vergleichende ökonomischökologische Analyse von biologisch und konventionell wirtschaftenden Betrieben in Luxemburg ("öko-öko"). Inst Für Biol Landwirtsch Agrar Luxembg 95.

SER, MA - Service d'Economie Rurale, Ministere de l'Agriculture, de la Viticulture et du Developpement Rural (2013) Die luxemburgische Landwirtschaft in Zahlen 2013. Serv Econ Rurale Minist Agric Vitic Dev Rural 30.

Stemann G, Lütke Entrup N (2001) Fruchtfolge mit Leguminosen: Effizient und kostensparend. Raps 1:200-207.
Stoddard FL, Nicholas AH, Rubiales D et al (2010) Integrated pest management in faba bean. Field Crops Res 115:308-318. doi:10.1016/j. fcr.2009.07.002

The American association for public opinion research (2011) Standard Definitions: Final Dispositions of Cases Codes and Outcome Rates for Surveys. Am Assoc Public Opin Res 61.

Vindis P, Mursec B, Janzekovic M, Cus F (2007) Processing of soybean meal into concentrates and testing for genetically modified organism (GMO). J Achiev Mater Manuf Eng 20:507-510

Voisin A-S, Guéguen J, Huyghe C et al (2014) Legumes for feed, food, biomaterials and bioenergy in Europe: a review. Agron Sustain Dev 34:361-380. doi:10.1007/s13593-013-0189-y

Von Richthofen J-S, Pfahl H (2006) European extension network for the development of grain legumes production in the EU "Gl-Pro". GLPro Final report Period March 2003- May 2006, Contract QLK5CT-2002-02 418. 90.

Wittenberg R, Cramer H (2003) Datenanalyse mit SPSS für Windows: mit zahlreichen Tabellen und Übersichten. Lucius \& Lucius, Stuttgart 